\title{
Asas Contarius Actus pada Perpu Ormas: Kritik dalam Perspektif Hukum Administrasi Negara dan Hak Asasi Manusia
}

\author{
Victor Imanuel W. Nalle* \\ DOI: https://doi.org/10.22304/pjih.v4n2.a2
}

\begin{abstract}
Abstrak
Peraturan Pemerintah Pengganti Undang-Undang Nomor 2 Tahun 2017 tentang Perubahan atas Undang-Undang Nomor 17 Tahun 2013 tentang Organisasi Kemasyarakatan mendapat kritik karena membatasi kebebasan berserikat dan memberi peluang pemerintah untuk mencabut status badan hukum organisasi kemasyarakatan tanpa melalui putusan pengadilan. Berdasarkan perspektif demokrasi deliberatif, tidak adanya proses deliberasi dalam pembentukan hukum dapat membuka peluang represi negara terhadap masyarakat sipil. Selain itu, berdasarkan perspektif rule of law, tidak adanya deliberasi dalam proses pengundangan memperlemah basis legitimasi dalam pembentukan hukum. Analisis dengan pendekatan konseptual dan perundang-undangan dalam tulisan ini menunjukkan bahwa walaupun pemerintah memiliki alasan yang kuat terkait aspek kekosongan hukum tetapi juga memiliki kelemahan substansial. Pertama, minimnya deliberasi di ruang publik dalam pembentukan Perpu Ormas melemahkan legitimasi. Kedua, lemahnya argumentasi penggunaan asas contrarius actus sebagai alasan mendesak untuk membentuk perpu. Ketiga, pembatasan terhadap kemerdekaan berserikat kontradiktif dengan jaminan dalam konstitusi, khususnya Pasal 28 dan Pasal 28J Undang-Undang Dasar 1945, yang secara tegas menyatakan bahwa pembatasan harus ditetapkan dengan undang-undang dan tidak menyebutkan perpu sebagai instrumen yang dapat membatasi derogable rights.
\end{abstract}

Kata kunci: contrarius actus, hak asasi manusia, hak berserikat, organisasi masyarakat, peraturan pemerintah pengganti undang-undang.

\section{Principle of Contarius Actus on Government Regulations in Lieu of Law on Mass Organization: Critiques from Administravite Law and Human Rights Perspectives}

\begin{abstract}
Government Regulation in Lieu of Law Number 2 of 2017 on Amendment of Law Number 17 of 2013 on Social Organizations (Perpu on Amendment to the Law on Social Organizations) is criticized for limiting freedom of association and allowing the government to revoke the status of legal body of social organizations without going through court decisions. Based on the perspective of deliberative democracy, the absence of a deliberation process in the legislation process can open up opportunities for state repression against civil society. Moreover, based on the rule of law perspective, the absence of deliberations in the legislation process undermines the legitimacy. The analysis with the conceptual and

PADJADJARAN Jurnal IImu Hukum Volume 4 Nomor 2 Tahun 2017 [ISSN 2460-1543] [e-ISSN 2442-9325]

* Dosen Fakultas Hukum Universitas Katolik Darma Cendika, Jl. Dr. Ir. H. Soekarno 201, Surabaya 60117, vicnalle@yahoo.com, S.H. (Universitas Brawijaya), M.H. (Universitas Airlangga).
\end{abstract}


legislative approach in this paper shows that although the government has strong reasons for the legal void aspects but also has substantial weaknesses. First, the lack of deliberation in the public sphere in the formation of the perpu can undermines legitimacy. Secondly, the use of contrarius actus principle as urgent reason is a weak argument for establishing the Perpu. Thirdly, restrictions on freedom of association contradict the guarantees of the constitution, particularly Article 28 and Article 28J of the 1945 Constitution, which expressly state that restrictions must be established by law and do not mention the perpu as an instrument that may limit derogable rights.

Keywords: contrarius actus, human rights, freedom of association, mass organization, government regulation in lieu of law.

\section{A. Pendahuluan}

Pemerintah pada tahun 2017 telah mengundangkan dua peraturan pemerintah pengganti undang-undang (perpu) yaitu Perpu Nomor 1 Tahun 2017 tentang Akses Informasi Keuangan untuk Kepentingan Perpajakan dan Perpu Nomor 2 Tahun 2017 tentang Perubahan atas Undang-Undang Nomor 17 Tahun 2013 tentang Organisasi Kemasyarakatan (Perpu Ormas). Berbeda dengan perpu yang pertama, Perpu Ormas menuai pro dan kontra. Kubu yang menolak Perpu Ormas direpresentasikan oleh beberapa organisasi kemasyarakat (ormas) Islam dan lembaga pro demokrasi yang mengkritik perpu tersebut sebagai kemunduran dalam demokratisasi Indonesia. Hizbut Tahrir Indonesia (HTI), ormas yang tampaknya menjadi sasaran dari perpu ini, berencana untuk mengajukan permohonan uji materiil ke Mahkamah Konstitusi (MK). Di sisi lain, kubu yang pro (salah satunya adalah Nahdlatul Ulama) memandang positif perpu ini dari perspektif kemanfaatannya dalam menangkal gerakan anti-Pancasila dan anti-Negara Kesatuan Republik Indonesia (NKRI).

Kritik terhadap Perpu Ormas didasarkan pada perspektif Hak Asasi Manusia (HAM). Perpu ini dianggap membatasi kebebasan berserikat yang telah dijamin dalam Undang-Undang Dasar Tahun 1945 (UUD 1945). Selain itu, mekanisme pembubaran tanpa melalui putusan pengadilan merupakan kemunduran jika dibandingkan dengan Undang-Undang Nomor 17 Tahun 2013 tentang Organisasi Kemasyarakatan (UU Ormas) yang mengatur mekanisme pembubaran berdasarkan putusan pengadilan. Di sisi lain, pihak yang sepakat terhadap perpu ini memandang ancaman radikalisme yang berasal dari gerakan ormas tertentu tidak dapat diatasi dalam waktu dekat jika harus menunggu putusan pengadilan terlebih dahulu. Sementara gerakan ormas yang radikalis tersebut semakin mengancam eksistensi Pancasila sebagai dasar negara.

Selain itu, pihak yang kontra juga mengkritik penggunaan asas contrarius actus sebagai dasar pembentukan Perpu Ormas. Koalisi Masyarakat Sipil Tolak Perpu Ormas dalam siaran persnya berpendapat alasan pemerintah yang menilai ketiadaan asas contrarius actus untuk membubarkan ormas berbadan hukum 
dalam UU Ormas tidaklah tepat dan bahkan tidak berdasar. Menurut Koalisi Masyarakat Sipil Tolak Perpu Ormas, tidak ada keharusan secara hukum lembaga yang memberikan pengesahan secara otomatis memiliki kewenangan mencabut atau membatalkan status badan hukum organisasi/entitas yang bersangkutan. Sudah sedemikian banyak lembaga, institusi, dan badan hukum yang tidak dapat dibubarkan oleh lembaga atau institusi yang mengesahkannya. Justru mekanisme pembubaran atau pencabutan status badan hukum umumnya mesti melalui mekanisme peradilan. ${ }^{1}$

Walaupun menjadi pro dan kontra, tetapi pemerintah akhirnya menggunakan Perpu Ormas tersebut sebagai landasan pembubaran HTI. HTI tercatat sebagai Badan Hukum Perkumpulan dengan Nomor Register AHU-00282.60.10.2014 pada 2 Juli 2014 dan kemudian, dengan mengacu pada Perpu Ormas, dicabut statusnya sebagai badan hukum dengan Surat Keputusan Menteri Hukum dan HAM No. AHU30.AH.01.08 Tahun 2017. Pencabutan tanpa melalui putusan pengadilan tersebut sesuai dengan yang telah diatur dalam Perpu Ormas yang didasarkan pada prinsip contrarius actus, bahwa pemerintah memiliki wewenang untuk mencabut kembali keputusan yang telah dibuatnya.

Terlepas dari segala aspek politis terkait pembubaran $\mathrm{HTI}$, permasalahan hukum ini perlu dianalisis dari perspektif yuridis normatif untuk menjawab pertanyaan utama, yaitu apakah pemerintah dapat membatasi kebebasan berserikat dengan didasarkan pada Perpu dan tanpa melalui putusan pengadilan? Untuk menjawab pertanyaan utama tersebut, tulisan ini akan menganalisis Perpu Ormas dari dua aspek. Pertama, konsep dasar perpu dengan kegentingan yang memaksa sebagai kondisi yang menjadi persyaratannya. Isu yang perlu dijawab dalam aspek pertama ini adalah ada tidaknya kegentingan yang memaksa sebagai latar belakang pembentukan perpu. Analisis terhadap kegentingan yang memaksa tersebut mencakup aspek kekosongan hukum dan kebutuhan mendesak. Kedua, konsiderans perpu beserta kelemahannya dari perspektif administrasi pemerintahan serta teknis perancangan (legal drafting). Isu yang perlu dijawab dalam aspek kedua ini adalah urgensi penggunaan prinsip contrarius actus dalam pembubaran ormas sehingga pembubaran ormas tidak perlu melalui putusan pengadilan.

\section{B. Konsep Kegentingan yang Memaksa dalam Peraturan Pemerintah Pengganti Perundang-undangan}

Perpu sebenarnya bukan jenis peraturan perundang-undangan yang hanya dapat ditemui di Indonesia. Negara lain juga memiliki konsep serupa dengan perpu dan

1 Rilis Pers Bersama Koalisi Masyarakat Sipil Tolak Perpu Ormas, "Perppu Ormas Ancaman Bagi Demokrasi dan Negara Hukum", Jakarta, 24 Juli 2017, dapat diakses dalam http://www.pshk.or.id/wp-content/uploads/ 2017/07/Siaran-Pers-Koalisi-Masyarakat-Sipil-Tolak-Perppu-Ormas-24Jul17.pdf. 
hanya berbeda dalam aspek penamaan atau prosedural pembentukannya. Inggris, misalnya, memiliki konsep fast-track legislation, yaitu undang-undang yang dibentuk dengan prosedur yang cepat atau di luar prosedur normal untuk membentuk suatu undang-undang. Fast-track legislation ini dapat ditempuh seperti untuk menindaklanjuti putusan pengadilan dan perjanjian internasional, mengatasi krisis ekonomi, terorisme, dan lain-lain. ${ }^{2}$ Selain Inggris, negara lain juga mengenal konsep hukum dalam keadaan darurat (emergency law) atau hukum dalam keadaan perang (martial law, state of siege).

Pada sistem hukum negara lain, pemberlakuan keadaan darurat diatur dalam konstitusi agar negara untuk secara efektif dapat melawan ancaman tanpa mengorbankan pengambilan keputusan demokratis atau jaminan dasar hak-hak fundamental. Pengaturan pemberlakuan keadaan darurat dalam konstitusi secara yuridis menguntungkan bagi sistem hukum. Pertama, pengaturan pemberlakuan keadaan darurat dalam konstitusi dapat berimplikasi pada perhatian yang lebih besar dapat diberikan untuk melindungi hak-hak individu dan membuat respons militer yang lebih efektif. Pada situasi darurat, cara pengambilan keputusan dan tindakan pemerintah melalui prosedur normal terlalu memberatkan untuk digunakan dalam situasi yang memerlukan tanggapan cepat. Oleh karena itu, keadaan darurat perlu memiliki mekanisme alternatif yang tercantum dalam konstitusi itu sendiri sehingga memastikan bahwa prinsip-prinsip dasar demokrasi dihormati, bahkan dalam situasi ketika demokrasi itu sendiri terancam. Kedua, kondisi darurat yang diatur secara konstitusional melindungi pelaksanaan sistem hukum sipil dalam kejadian darurat. Pendekatan ini sering disebut sebagai konsep dualisme konstitusional. Konsep dualisme konstitusional didasarkan pada anggapan bahwa harus ada ketentuan untuk dua sistem hukum yang beroperasi dalam keadaan normal untuk melindungi hak dan kebebasan, serta hal lain yang sesuai untuk menghadapi keadaan darurat. $^{3}$

Aspek keadaan darurat dalam pembentukan perpu dapat ditemukan pada Pasal 22 ayat (1) UUD 1945 yang mengatur bahwa, "Dalam hal ihwal kegentingan yang memaksa, Presiden berhak menetapkan peraturan pemerintah sebagai pengganti undang-undang." Berdasarkan rumusan yang singkat tersebut, maka frasa kunci dalam memahami perpu adalah 'kegentingan yang memaksa'. Jika merujuk pada Risalah Sidang Badan Penyelidik Usaha-Usaha Persiapan Kemerdekaan Indonesia (BPUPKI), maka tidak ditemukan adanya pembahasan yang mendalam mengenai konsep perpu.

2 Committee on the Constitution, Fast-track Legislation: Constitutional Implications and Safeguards (15 ${ }^{\text {th }}$ Report of Session 2008-09), London: House of Lords UK Parliament, 2009.

3 William Feldman, "Theories of Emergency Powers: A Comparative Analysis of American Martial Law and the French State of Siege", Cornell International Law Journal, Vol. 38, Issue 3, 2005, hlm. 1040-1041. 
Pengaturan Perpu perpu Pasal 22 UUD hanya sempat disinggung dalam Sidang Pertama Panitia Persiapan Kemerdekaan Indonesia (PPKI) pada 18 Agustus 1945. Pada sidang tersebut, Otto Iskandardinata mengklarifikasi pengaturan perpu:

"Jadi Peraturan Pemerintah itu harus mendapat persetujuan Dewan Perwakilan Rakyat dalam sidangnya. Dalam prakteknya Presiden akan ditunjuk. Nanti Presiden harus mengadakan peraturan yang harus disahkan oleh Dewan Perwakilan Rakyat yang belum kita bentuk. Bagaimana dalam hal ini?"4

Terhadap pertanyaan tersebut, Soepomo memberikan jawaban singkat bahwa hal tersebut sudah termasuk dalam peraturan peralihan. ${ }^{5}$ Tidak adanya dinamika pembahasan konsep perpu dalam sidang BPUPKI dan PPKI menunjukkan bahwa tidak ada elaborasi yang mendalam terhadap konsep tersebut.

Pemahaman terhadap konsep perpu dapat dilihat pada bagian Penjelasan UUD 1945 sebelum amandemen. Pasal 22 yang mengatur konsep perpu merupakan salah satu pasal dalam UUD 1945 yang tidak mengalami amandemen. Oleh karena itu, walaupun bagian Penjelasan UUD 1945 telah dihapus dalam amandemen tetapi penjelasan frasa 'kegentingan yang memaksa' masih dapat ditelusuri pada bagian Penjelasan tersebut maupun gagasan yang melatarbelakanginya. Penjelasan Pasal 22 UUD 1945 (sebelum amandemen) menjelaskan sebagai berikut:

"Pasal ini mengenai noodverordeningsrecht Presiden. Aturan sebagai ini memang perlu diadakan agar supaya keselamatan negara dapat dijamin oleh pemerintah dalam keadaan yang genting, yang memaksa pemerintah untuk bertindak lekas dan tepat. Meskipun demikian, pemerintah tidak akan terlepas dari pengawasan Dewan Perwakilan Rakyat. Oleh karena itu, peraturan pemerintah dalam pasal ini, yang kekuatannya sama dengan undang-undang harus disahkan pula oleh Dewan Perwakilan Rakyat."6

Walaupun bagian Penjelasan UUD 1945 telah mencoba mengurai frasa 'kegentingan yang memaksa', akan tetapi sebenarnya indikator dari 'kegentingan yang memaksa' tidak cukup jelas. UUD 1945 hanya menunjukkan ciri kegentingan tersebut melalui ketentuan di ayat (2) yang menyatakan bahwa perpu harus mendapat persetujuan Dewan Perwakilan Rakyat (DPR) dalam persidangan yang berikut. Kegentingan yang memaksa secara harfiah hanya dapat didefinisikan sebagai kondisi yang tidak normal, tetapi tidak mampu menjelaskan kondisi

$4 \quad$ Ananda B. Kusuma, (et.al.) (ed.), Risalah Sidang Badan Penyelidik Usaha-Usaha Persiapan Kemerdekaan Indonesia, Jakarta: Sekretariat Negara Republik Indonesia, 1992, hlm. 320

5 Ibid.

6 Bagian Penjelasan Undang-Undang Dasar Negara Republik Indonesia Tahun 1945 (UUD 1945) (sebelum amandemen) sebenarnya tidak pernah disahkan oleh Panitia Persiapan Kemerdekaan Indonesia (PPKI) pada tanggal 18 Agustus 1945. Bagian tersebut disusun oleh Soepomo setelah UUD 1945 berlaku. Namun, bagian tersebut baru terintegrasi dalam naskah UUD 1945 setelah Dekrit Presiden. 
kegentingan yang memaksa dalam indikator yang terukur. ${ }^{7}$ Lemahnya kriteria kegentingan karena tanpa indikator yang jelas dapat dilihat pada jumlah perpu pada tahun 1960 (pasca-Dekrit Presiden) yang mencapai 56 judul. Jumlah perpu tersebut dapat menyiratkan adanya keadaan genting atau justru kondisi sebaliknya, yaitu kriteria yang kabur sehingga pemerintah dapat menafsirkannya secara luas. ${ }^{8}$

Indikator 'kegentingan yang memaksa' kemudian dirumuskan oleh MK pada tahun 2009. Putusan MK Nomor 138/PUU-VII/2009 tentang Permohonan Pengujian Perpu Nomor 4 Tahun 2009 tentang Perubahan atas Undang-Undang Nomor 30 Tahun 2002 tentang Komisi Pemberantasan Tindak Pidana terhadap UUD 1945 yang diucapkan dalam sidang pleno terbuka pada hari Senin, 8 Februari 2010 (Putusan MK No. 138/PUU-VII/2009) menjelaskan persyaratan keadaan 'kegentingan yang memaksa' dalam 3 (tiga) kondisi, yaitu:

a. adanya kebutuhan mendesak untuk menyelesaikan masalah hukum secara cepat berdasarkan undang-undang;

b. undang-undang yang dibutuhkan tersebut belum ada (kekosongan hukum) atau ada undang-undang tetapi tidak memadai; dan

c. kekosongan hukum tersebut tidak dapat diatasi dengan membuat undangundang secara prosedur biasa karena akan membutuhkan waktu yang lama.

Pendapat MK tersebut tidak berbeda dengan pendapat Jimly Asshiddiqie mengenai unsur penting 'kegentingan yang memaksa'. Menurut Jimly Asshiddiqie, 'kegentingan memaksa' sebagai syarat perpu memiliki tiga syarat, yaitu: ancaman yang membahayakan (dangerous threats); kebutuhan yang mengharuskan (reasonable necessity); dan/atau keterbatasan waktu (limited time). ${ }^{9}$ Sementara itu Binsar Gultom memiliki pendapat berbeda dengan Jimly Asshiddiqie. Menurut Binsar Gultom, perpu tidak menyaratkan adanya ancaman yang membahayakan. Kriteria kegentingan yang memaksa dalam pembentukan perpu lebih menekankan aspek kebutuhan yang mengharuskan (reasonable necessity), dan/atau keterbatasan waktu (limited time). Oleh karena itu, pembentukan perpu menurut Gultom tidak mensyaratkan adanya keadaan bahaya (dangerous threats), baik yang diumumkan secara resmi maupun tidak diumumkan. ${ }^{10}$

Persyaratan kondisi dalam kegentingan yang memaksa dalam membentuk perpu dapat dijustifikasi pada dua argumentasi. Pertama, bahwa pranata-pranata

7 Reza Fikri Febriansyah, "Eksistensi dan Prospek Pengaturan Perpu Dalam Sistem Norma Hukum Negara Republik Indonesia", Jurnal Legislasi Indonesia, Vol. 8, No. 4, 2012, hlm. 670.

8 Relativitas kegentingan dalam perspektif pemerintah dapat ditemukan pada Peraturan Pemerintah Pengganti Undang-Undang Nomor 5 Tahun 1963 tentang Surat Hutang Landreform. Perppu ini kemudian disahkan menjadi Undang-Undang Nomor 6 Tahun 1964 tentang Surat Hutang Landreform. Perppu ini tidak pernah efektif dilaksanakan saat itu dan juga sekarang karena UU tersebut belum pernah dicabut atau diganti oleh undang-undang lain.

9 Jimly Asshiddiqie, Hukum Tata Negara Darurat, Jakarta: PT. RajaGrafindo Persada, 2007, hlm. 207-208.

10 Binsar Gultom, Pelanggaran HAM dalam Hukum Keadaan Darurat di Indonesia: Mengapa Pengadilan HAM Ad Hoc di Indonesia Kurang Efektif?, Jakarta: PT Gramedia Pustaka Utama, 2010, hlm. 116-117. 
institusi republik, dalam rangka melindungi kebebasan, terlalu merepotkan jika digunakan dalam situasi genting dan oleh karena itu dibutuhkan pranata khusus untuk mempertahankan eksistensi negara. Kedua, bahwa berjalannya sistem hukum secara normal perlu dibedakan dengan berjalannya sistem hukum dalam kondisi genting. ${ }^{11}$

Argumentasi pertama dibangun dari proposisi bahwa undang-undang merupakan instrumen hukum yang dapat digunakan untuk melindungi kebebasan atau sebaliknya, membatasi kebebasan. Situasi darurat kemudian memaksa negara untuk membatasi kebebasan, namun pembatasan tersebut tidak memungkinkan jika dilakukan dengan instrumen undang-undang karena situasi darurat yang harus segera diatasi oleh pemerintah. Terlebih lagi, apabila pembatasan kebebasan tersebut menggunakan undang-undang, maka prosedur yang harus dilewati terlalu lama dalam konteks kedaruratan negara.

Argumentasi pertama yang didasarkan pada situasi darurat dapat dibenarkan jika hukum dilihat dari perspektif instrumentalis. Namun argumentasi tentang peran instrumental hukum akan lemah jika dikritik dari perspektif legitimasi. Kritik terhadap instrumentalisme perpu dari perspektif legitimasi mengacu pada dua konsep, yaitu demokrasi deliberatif dan rule of law. Jika konsep demokrasi deliberatif dikontekstualkan dengan pembentukan hukum, maka konsekuensinya pembentukan hukum harus melalui proses deliberasi di ruang publik. Deliberasi di ruang publik menempatkan rasionalitas komunikatif sebagai partisipasi rasio yang diarahkan untuk mencapai intersujektivitas berupa konsensus. Konsep demokrasi deliberatif dengan demikian mendefinisikan hukum tidak sekedar sebagai produk politik, melainkan produk komunikasi. ${ }^{12}$ Jika pembatasan kebebasan berserikat dilakukan dengan instrumen perpu maka secara prosedural menutup kemungkinan deliberasi dan melemahkan legitimasi pembatasan tersebut. Selain itu, secara normatif pembatasan kebebasan berserikat dengan perpu bertentangan dengan Pasal 28 UUD 1945 yang menyatakan bahwa kemerdekaan berserikat dan berkumpul, mengeluarkan pikiran dengan lisan dan tulisan dan sebagainya ditetapkan dengan undang-undang. Artinya, pembentuk UUD 1945 telah menyadari bahwa pembatasan hak berserikat seharusnya memiliki legitimasi yang kuat.

Konsep rule of law juga menjadi syarat elementer bagi legitimasi pembentukan hukum. Premis mendasar dari rule of law dalam pembentukan hukum adalah bahwa setiap undang-undang dapat dijustifikasi publik. Menurut Tatsuo Inoue, salah satu prinsip struktural dalam rule of law adalah adanya pengundangan

11 John Ferejohn dan Pasquale Paquino, "The Law of the Exception: A Typology of Emergency Powers", International Journal of Constitutional Law, Vol. 2, No. 2, 2004, hlm. 233-234.

12 Lihat Victor Imanuel W. Nalle, Menggagas Hukum Berbasis Rasionalitas Komunikatif, Malang: UB Press, 2010. 
(promulgation) dalam pembentukan hukum. Pengundangan bukan hanya terkait dengan publisitas materi muatan produk hukum. Prinsip pengundangan juga membutuhkan publisitas dalam basis justifikasi. Oleh karena itu, menurut Inoue, pembentukan hukum yang mengacu pada konsep rule of law seharusnya memberi kesempatan proses deliberasi agar berbagai data dapat dipertimbangkan dalam proses tersebut. ${ }^{13}$

Argumentasi kedua didasarkan pada konsep teoretis hukum tata negara darurat yang membedakan hukum dalam situasi normal dan hukum dalam situasi di luar normal. Ketika situasi tidak sedang dalam keadaan normal, maka sistem yang digunakan seharusnya sistem hukum dalam keadaan di luar normal. ${ }^{14}$ Pada situasi yang tidak normal, menurut Ferejohn dan Paquino, konstitusi dapat mengatur 4 (empat) dimensi kedaruratan, yaitu: ${ }^{15}$

a. Pernyataan keadaan darurat (qua declaration): Konstitusi seharusnya mengatur mekanisme pernyataan keadaan darurat yang biasanya dilakukan oleh eksekutif. Pasal 12 UUD 1945 memang mengatur wewenang presiden untuk menyatakan keadaan bahaya, tetapi pernyataan keadaan bahaya tidak menjadi syarat untuk pembentukan perpu. Menurut Herman Sihombing, mekanisme pernyataan keadaan darurat merupakan bentuk berlakunya hukum tata negara darurat objektif. Hukum tata negara darurat objektif memungkinkan pemerintah melakukan pengenyampingan dan penghapusan hak asasi tertentu dalam instrumen peraturan perundang-undangan karena adanya keadaan bahaya, keadaan perang, dan lain-lain; ${ }^{16}$

b. Pelaksanaan kekuasaan dalam keadaan darurat (qua exercise): Konstitusi seharusnya mengatur perihal cabang kekuasaan yang dapat melaksanakan pemerintahan dalam keadaan darurat;

c. Pengakhiran keadaan darurat (qua reestablishment of normality); dan/atau

d. Kontrol terhadap pelaksanaan kekuasaan dalam keadaan darurat (qua control on the effects of the emergency measures).

Pertanyaannya: bagaimana presiden menentukan terpenuhi atau tidaknya tiga kondisi tersebut? Apakah ketiga kondisi tersebut dapat menjadi kriteria yang objektif? Putusan MK No. 138/PUU-VII/2009 menjelaskan bahwa penilaian terhadap syarat kondisi tersebut merupakan hak subjektif presiden. Kewenangan pembentukan perpu menurut UUD 1945 hanya diberikan kepada presiden, termasuk kewenangan untuk menetapkan ada atau terjadinya hal keadaan darurat negara. Kewenangan ini sifatnya atributif (atributie van wet wegeven demacht) yang

13 Tatsuo Inoue, "The Rule of Law as Law of Legislation", dalam buku Legislation in Context: Essays in Legisprudence yang disusun oleh Luc J. Wintgens (ed), Hampshire: Ashgate Publishing Limited, 2007, hlm. 71.

14 John Ferejohn dan Pasquale Paquino, Op.cit., hlm. 223.

15 Ibid., hlm. 230.

16 Herman Sihombing, Hukum Tata Negara Darurat di Indonesia. Jakarta: Djambatan, 1996, hlm. 36. 
juga melahirkan tanggung jawab kepada presiden. Oleh karena itu, kewenangan tersebut bersifat subjektif artinya hak untuk menetapkan perpu didasarkan atas penilaian subjektif dari presiden sendiri mengenai adanya keadaan darurat negara (state of emergency) yang menimbulkan kegentingan yang memaksa. ${ }^{17}$

Pengawasan terhadap hak subjektif presiden kemudian dilakukan oleh DPR ketika perpu tersebut harus mendapat persetujuan DPR dalam persidangan yang berikutnya. Rumusan 'mendapat persetujuan DPR' menunjukkan bahwa wewenang DPR adalah menolak atau menerima perpu. Jika DPR menerima perpu, maka perpu akan disahkan menjadi undang-undang, sedangkan jika ditolak maka perpu tersebut akan dicabut. Mekanisme ini sebenarnya membingungkan dari konsep state of emergency karena emergency law seharusnya berlaku untuk sementara waktu, tetapi perpu justru dapat ditetapkan menjadi undang-undang dan berlaku tanpa batasan waktu. Oleh karena itu, nomenklatur perpu merupakan jenis yang berbeda dengan emergency law dan lebih menyerupai fast-track legis/ation tetapi dengan prosedur yang berbeda.

Pengawasan terhadap perpu juga dapat dilakukan dengan mengajukan permohonan judicial review ke MK. Putusan MK No. 138/PUU-VII/2009 menjadi preseden bahwa MK berwenang melakukan pengujian perpu dengan argumentasi kedudukan perpu setara dengan undang-undang, yang merupakan objek pengujian di MK, dan dibentuk dalam keadaan memaksa. Adanya wewenang MK untuk menguji perpu membuat konsep state of emergency di Indonesia mengalami pergeseran secara teoretis. Sebelum MK memutuskan berwenang menguji perpu, state of emergency di Indonesia menganut paradigma yang berorientasi pada negara (state-centered-theories). Paradigma berorientasi pada negara cenderung mengabaikan teks konstitusi dengan justifikasi adanya kebijaksanaan pemerintah untuk mengatasi kegentingan secara efektif. Adanya wewenang pengujian perpu oleh MK sebelum dinilai oleh DPR mengakibatkan paradigma state of emergency Indonesia cenderung berorientasi pada konstitusi (constitution-centered-theories) yang menekankan kepatuhan pada konstitusi atas dasar kekhawatiran terhadap penyalahgunaan wewenang dalam situasi genting. ${ }^{18}$

Jika Perpu Ormas menyasar pada ormas-ormas radikal, khususnya HTI, maka penafsiran kriteria kegentingan yang memaksa dalam konteks tersebut merupakan hak subjektif presiden. Namun demikian, penafsiran terhadap kriteria tersebut minimal harus menjawab beberapa isu berikut:

17 Muhammad Syarif Nuh, "Hakekat Keadaan Darurat Negara (State Of Emergency) sebagai Dasar Pembentukan Peraturan Pemerintah Pengganti Undang-Undang", Jurnal Hukum IUS QUIA IUSTUM, Vol. 18, No. 2, 2011, hlm. 238.

18 Paradigma state of emergency dapat dilihat pada András Jakab, "German Constitutional Law and Doctrine on State of Emergency-Paradigms and Dilemmas of a Traditional (Continental) Discourse", German Law Journal, Vol. 7, No. 5, 2006. 
a. Bagaimana tingkat ancaman yang membahayakan dari ormas radikal seperti HTI terhadap keberlangsungan negara? Menurut penulis, tingkat ancaman yang membahayakan tersebut harus dapat dibuktikan dengan adanya tindakan/ kegiatan konkrit secara terorganisir. Penafsiran terhadap 'ancaman yang membahayakan' juga harus dapat menunjukkan bahwa ormas radikal telah melakukan tindakan/kegiatan dalam tahap lanjut, misalnya tindakan/kegiatan untuk mengganti pemerintahan dalam bentuk mobilisasi massa atau membentuk opini publik untuk mencapai tujuan tersebut;

b. Apakah UU Ormas yang ada tidak mampu mengatasi ancaman yang membahayakan tersebut? Kriteria ini tidak dapat dilepaskan dari kriteria pertama. Ancaman yang membahayakan tersebut harus tidak diatur dalam UU Ormas sehingga pemerintah harus mengatasinya dengan mengaturnya dalam perpu. Salah satu kelemahan UU Ormas adalah hanya mendefinisikan 'paham yang bertentangan dengan Pancasila' dalam lingkup ideologi ateisme, komunisme/ Marxisme-Leninisme. Batasan tersebut menghambat pemerintah untuk mengambil tindakan terhadap ormas dengan ideologi lain yang secara aktual telah mengancam keberlangsungan negara. Dalam konteks ini, kriteria kekosongan hukum menjadi terpenuhi sebagai legitimasi bagi pemerintah dalam membentuk perpu. Tampaknya perancang UU Ormas dahulu gagal mengelaborasi spektrum ideologi yang bertentangan dengan Pancasila;

c. Apakah waktu yang dibutuhkan untuk membuat UU Ormas yang baru atau undang-undang perubahan membutuhkan waktu yang terlampau lama sehingga ancaman tersebut justru akan makin membahayakan negara? Penyusunan undang-undang baru bukan proses yang sederhana. Waktu yang dibutuhkan harus terpotong dengan masa reses dan bahkan harus diprogramkan dalam Program Legislasi Nasional (Prolegnas). Tafsiran terhadap waktu yang dibutuhkan ini harus mampu menunjukkan bahwa waktu yang dibutuhkan dalam membuat undang-undang baru justru akan makin berbahaya karena aktivitas ormas tersebut dikhawatirkan akan makin membesar.

\section{Kelemahan Aspek Perancangan (Legal Drafting) dan Prinsip Contrarius Actus dalam Peraturan Pemerintah Pengganti Undang-Undang Nomor 2 Tahun 2017 tentang Perubahan atas Undang-Undang Nomor 17 Tahun 2013 tentang Organisasi Kemasyarakatan}

Norma hukum Perpu Ormas didasarkan pada faktor sosial, politik, dan yuridis yang dapat ditemukan pada bagian konsideransnya. Tulisan ini hanya difokuskan pada faktor yuridis yang menjadi landasan dari perpu. Berdasarkan pada bagian konsideransnya, Perpu Ormas didasarkan pada dua argumentasi yuridis, yakni:

Pertama, UU Ormas belum mengatur secara komprehensif mengenai ke-ormasan yang bertentangan dengan Pancasila dan UUD 1945 sehingga terjadi kekosongan 
hukum dalam menerapkan sanksi yang efektif. ${ }^{19}$ Substansi perpu dalam kaitannya dengan argumentasi ini menambahkan dua materi larangan terhadap ormas, yaitu:

1) larangan menggunakan nama, lambang, bendera, atau simbol organisasi yang sama (pada pokok atau keseluruhan) dengan nama, lambang, bendera, atau simbol organisasi gerakan separatis atau terlarang;

2) larangan melakukan kegiatan separatis yang mengancam kedaulatan NKRI.

Substansi perpu juga menambahkan bagian Penjelasan Pasal 59 untuk memperjelas ruang lingkup larangan "melakukan tindakan permusuhan terhadap suku, agama, ras, atau golongan" dan "menganut, mengembangkan, serta menyebarkan ajaran atau paham yang bertentangan dengan Pancasila". Tindakan permusuhan yang dilarang dalam perpu mencakup ucapan, pernyataan, sikap atau aspirasi (lisan dan tertulis) melalui media elektronik atau non-elektronik yang menimbulkan kebencian terhadap kelompok tertentu, setiap orang, dan penyelenggara negara. Larangan terhadap paham yang bertentangan dengan Pancasila juga diperluas sehingga bukan hanya mencakup ajaran ateisme, komunisme/ Marxisme-Leninisme, tetapi juga paham lain yang bertujuan mengganti/mengubah Pancasila dan UUD 1945.

Perluasan larangan permusuhan sehingga mencakup pula permusuhan terhadap penyelenggara negara menuai kritik karena berpotensi mengkriminalisasi pihak-pihak yang mengkritik pemerintah. Pandangan kontra tersebut sebenarnya terbuka untuk diperdebatkan karena aspek materiil dalam unsur 'menimbulkan kebencian' dapat memperjelas perbedaan antara kritik terhadap kebijakan pemerintah dan sikap anti-pemerintah (atau bahkan anti-negara) yang sebenarnya menjadi sasaran dari perpu ini.

Kelemahan dari perluasan larangan permusuhan tersebut justru pada aspek perancangan (drafting) bagian Penjelasan. Padahal, Undang-Undang Nomor 12 Tahun 2011 tentang Pembentukan Peraturan Perundang-undangan (UU P3U) membatasi materi muatan yang dapat dicantumkan dalam bagian penjelasan. Penjelasan seharusnya tidak boleh mencantumkan rumusan yang berisi norma dan rumusan yang isinya memuat perubahan terselubung terhadap ketentuan peraturan perundang-undangan. ${ }^{20}$ Pasal 59 ayat (3) Perpu Ormas sebenarnya merumuskan sasaran dari tindakan permusuhan adalah suku, agama, ras, atau golongan. Oleh karena itu, bagian penjelasan seharusnya memberikan tafsiran terhadap istilah: tindakan permusuhan, suku, agama, ras, golongan. Namun, substansi penjelasan justru memperluas norma Pasal 59 ayat (3) sehingga penyelenggara negara menjadi bagian dari sasaran tindakan permusuhan.

\footnotetext{
19 Konsiderans Menimbang huruf c Peraturan Pemerintah Pengganti Undang-Undang Nomor 2 Tahun 2017.

20 Lihat Lampiran Undang-Undang Nomor 12 Tahun 2011 tentang Pembentukan Peraturan PerundangUndangan (Nomor 177 dan 178).
} 
Kedua, UU Ormas belum menganut asas contrarius actus sehingga tidak efektif untuk menerapkan sanksi terhadap ormas yang menganut, mengembangkan, serta menyebarkan ajaran atau paham yang bertentangan dengan Pancasila dan UUD 1945. ${ }^{21}$ Asas contrarius actus adalah asas yang berasal dari tradisi hukum Romawi yang memberi wewenang kepada pemerintah untuk menarik kembali keputusan/ peraturan yang dibuatnya dengan ketentuan bahwa penarikan keputusan/ peraturan tersebut dilakukan oleh lembaga yang membuatnya.

Asas contrarius actus sebenarnya melekat pada pejabat pemerintah tanpa perlu ditegaskan dalam peraturan perundang-undangan. Sebenarnya setiap pejabat pemerintah dapat menarik kembali keputusan yang dibuatnya walaupun wewenang tersebut tidak disebutkan secara eksplisit dalam peraturan perundangundangan yang terkait, dalam konteks ini adalah UU Ormas.

Secara umum, asas contrarius actus telah tercantum secara eksplisit dalam Pasal 33 ayat (3) Undang-Undang Nomor 30 Tahun 2014 tentang Administrasi Pemerintahan (UU Administrasi Pemerintahan). Pencabutan kembali suatu keputusan juga harus mengacu pada kriteria atau batasan yang telah diatur dalam UU Administrasi Pemerintahan, yaitu apabila ada cacat wewenang, prosedur, dan/atau substansi (Pasal 64 UU Administrasi Pemerintahan). Alasan pencabutan status badan hukum ormas dalam konteks ormas radikal dapat digolongkan dalam kriteria cacat subtansi. Penjelasan Pasal 64 UU tersebut mendefinisikan cacat subtansi, salah satunya, jika keputusan yang dikeluarkan ternyata dapat membahayakan dan merugikan kepentingan umum.

Oleh karena itu, kedudukan Perpu Ormas dalam rangka mempertegas asas contrarius actus secara normatif tidak tepat. Perpu tersebut secara substansial justru lebih ditujukan untuk memperjelas ruang lingkup membahayakan dan merugikan kepentingan umum dalam konteks ke-ormas-an. Salah satu bentuknya adalah memberikan definisi-definisi yang lebih tegas terhadap ruang lingkup larangan bagi ormas.

Melanjutkan dua argumentasi di atas, penggunaan asas contrarius actus dalam pembubaran ormas justru merupakan substansi yang mendapat kritik tajam karena pembubaran ormas dapat dilakukan dengan mencabut status badan hukumnya. Padahal dalam UU Ormas sebelum diubah oleh Perpu Ormas, pembubaran ormas tidak dapat langsung dilakukan melalui pencabutan status badan hukum oleh pemerintah melainkan dengan putusan pengadilan. Argumentasi dari kritik ini adalah perspektif HAM, khususnya tentang kemerdekaan berserikat dan mengeluarkan pendapat. Pembubaran ormas tanpa putusan pengadilan dikhawatirkan akan membuat pemerintah (eksekutif) terjebak pada praktik otoritarianisme seperti yang dilakukan Orde Baru. Menurut Penulis, kritik dengan

21 Konsiderans Menimbang huruf e Peraturan Pemerintah Pengganti Undang-Undang Nomor 2 Tahun 2017. 
perspektif HAM juga perlu melihat kedudukan hak berserikat sebagai kategori HAM dalam hukum internasional maupun UUD 1945. Isu yang perlu dicermati adalah apakah negara dapat membatasi hak berserikat dengan instrumen undang-undang. Jika negara boleh membatasi hak berserikat, apakah pembatasan dalam bentuk pembubaran hanya dapat dilakukan melalui pengadilan?

Hukum internasional, melalui Kovenan Internasional tentang Hak Sipil dan Politik (International Covenant on Civil and Political Rights-ICCPR), ${ }^{22}$ telah mengatur berbagai macam HAM dalam ruang lingkup hak sipil dan politik. Pasal 22 ayat (1) ICCPR menjamin hak setiap orang untuk berserikat dengan orang lain, termasuk hak untuk membentuk dan bergabung dalam serikat pekerja untuk melindungi kepentingannya. Hak tersebut tidak dapat dibatasi kecuali jika dibatasi oleh undangundang dengan tujuan untuk kepentingan keamanan nasional dan keselamatan publik, ketertiban umum, perlindungan kesehatan dan moral publik, atau perlindungan atas hak dan kebebasan dari orang lain [Pasal 22 ayat (2)]. Ketentuan dalam ICCPR dengan demikian menegaskan posisi hak berserikat sebagai hak yang dapat dibatasi (derogable rights).

Pasal 4 ayat (1) ICCPR juga membolehkan negara untuk melakukan pembatasan terhadap hak sipil dan politik dalam keadaan darurat. Kondisi tersebut dapat dibenarkan sepanjang tindakan negara dalam keadaan darurat tersebut tidak mengakibatkan diskriminasi atas dasar ras, warna kulit, jenis kelamin, bahasa, agama atau asal usul sosial. Namun demikian, Pasal 4 juga menekankan pentingnya pengumuman kondisi darurat secara resmi sebelum negara melakukan pembatasan hak sipil dan politik. Selain itu, kondisi darurat yang berimplikasi pada pengenyampingan hak sipil dan politik harus memiliki jangka waktu keberlakuan sehingga negara tidak dapat melakukan pembatasan tanpa jangka waktu yang jelas. Artinya, kondisi darurat tersebut harus dimaknai sebagai kondisi yang sementara. Komentar Umum terhadap Pasal 4 ICCPR menegaskan syarat tersebut. ${ }^{23}$

Pasal 4 ICCPR telah menimbulkan sejumlah persoalan bagi komite ketika akan mempertimbangkan laporan dari beberapa negara pihak. Ketika suatu kondisi gawat darurat publik yang mengancam kehidupan negara muncul dan diumumkan secara resmi, suatu negara pihak dapat menderogasi sejumlah hak sampai pada tingkatan yang diizinkan oleh situasi tersebut. Namun demikian, negara pihak tidak boleh melakukan derogasi beberapa hak khusus dan tidak boleh melakukan langkah-langkah diskriminatif atas dasar beberapa alasan. Negara pihak juga berkewajiban untuk segera memberikan informasi kepada negara-negara pihak

22 Kovenan ini telah diratifikasi oleh Indonesia pada 28 Oktober 2005 melalui Undang-Undang Nomor 12 Tahun 2005 tentang Pengesahan International Covenant on Civil and Political Rights (Kovenan Internasional tentang Hak-Hak Sipil dan Politik).

23 Komisi Nasional Hak Asasi Manusia, Komentar umum Kovenan Internasional Hak Sipil dan Politik, Kovenan Internasional Hak Ekonomi, Sosial, dan Budaya, Jakarta: Komisi Nasional Hak Asasi Manusia, 2009, hlm. 7. 
lainnya melalui sekretaris jenderal mengenai derogasi yang telah dilakukan, termasuk alasan-alasannya serta tanggal di mana derogasi tersebut akan diakhiri.

Selain itu, hukum internasional mengenal Prinsip Siracusa (Siracusa Principles) yang mengatur mengenai ketentuan pembatasan dan pengurangan hak yang diatur di dalam ICCPR. Prinsip-prinsip ini dihasilkan oleh sekelompok ahli hukum internasional yang bertemu di Siracusa, Italia, pada April dan Mei 1984. Berdasarkan Prinsip Siracusa, pembatasan terhadap hak sipil dan politik (termasuk hak berserikat) dapat dilakukan jika diperlukan. Pembatasan hak berserikat diperlukan jika memenuhi empat kriteria. Pertama, didasarkan pada salah satu alasan yang dibenarkan dalam kovenan. Kedua, menjawab kebutuhan sosial. Ketiga, mencapai tujuan yang sah. Keempat, proporsional pada tujuan di atas. ${ }^{24}$ Pembatasan tersebut harus dilakukan dengan instrumen undang-undang atau putusan pengadilan dan tujuan yang sah sebagai dasar untuk melakukan pembatasan tersebut setidaknya bertujuan untuk:25

a. menjaga tatanan masyarakat demokratis;

b. melindungi ketertiban umum;

c. melindungi kesehatan publik (public health);

d. melindungi moral publik (public moral);

e. melindungi keamanan nasional (public security);

f. melindungikemanan publik; dan

g. melindungi hak dan kemerdekaan warga negara lainnya.

Sebelum ICCPR diratifikasi oleh Indonesia pada tahun 2005, UUD 1945 Setelah Amandemen telah memberikan kriteria tentang hak asasi yang tidak dapat dibatasi dan alasan-alasan pembatasan hak asasi. Pasal 28I ayat (1) UUD 1945 telah memberikan kriteria hak asasi yang tidak dapat dibatasi oleh undang-undang, antara lain hak untuk hidup, hak untuk tidak disiksa, hak kemerdekaan pikiran dan hati nurani, hak beragama, hak untuk tidak diperbudak, hak untuk diakui sebagai pribadi di hadapan hukum, dan hak untuk tidak dituntut atas dasar hukum yang berlaku surut. Hak asasi selain yang disebutkan tersebut dapat dibatasi dengan alasan untuk menjamin pengakuan serta penghormatan atas hak dan kebebasan orang lain dan untuk memenuhi tuntutan yang adil sesuai dengan pertimbangan moral, nilai-nilai agama, keamanan, dan ketertiban umum.

Wewenang negara untuk membatasi hak berserikat juga ditegaskan oleh MK dalam Putusan MK No. 82/PUU-XI/2013 perihal Pengujian UU Ormas terhadap UUD 1945 yang diucapkan secara terbuka pada hari Selasa, 23 Desember 2014. MK berpendapat:

24 The Siracusa Principles on the Limitation and Derogation Provisions in the International Covenant on Civil and Political Rights, E/CN.4/1985/4.

25 Victor Imanuel W. Nalle, "Blasphemy Law and Public Neutrality in Indonesia", Mediterannean Journal of Social Sciences, Vol. 8, No. 2, 2017, hlm. 60-61. 
“....jika kegiatan dan aktivitas Ormas terbukti mengancam keamanan dan ketertiban umum, mengganggu hak kebebasan orang lain, serta melanggar nilai-nilai moral dan nilai-nilai agama, negara berkewajiban dalam fungsinya menjamin ketertiban umum dapat melakukan penegakan hukum, bahkan dapat menghentikan kegiatan suatu Ormas."

ICCPR dan UUD 1945 menunjukkan bahwa pemerintah memiliki peran untuk melakukan pembatasan kebebasan berserikat jika kebebasan tersebut ternyata dapat mengancam keamanan nasional dan ketertiban umum. Namun demikian, pemerintah harus dapat menjelaskan bentuk ancaman yang nyata dihadapi dan dapat mengancam keamanan nasional dan ketertiban umum tersebut. Pembatasan tersebut juga hanya dapat dilakukan melalui undang-undang. Kriteria terakhir ini akan memunculkan pertanyaan baru: apakah pembatasan hak berserikat melalui perpu, yang berarti tidak melalui proses legislasi di DPR, merupakan pembatasan yang konstitusional berdasarkan Pasal 28J UUD 1945? Atau jika dielaborasi lebih lanjut: apakah suatu keadaan genting dapat menjadi legitimasi bagi pemerintah untuk membatasi hak berserikat tanpa menggunakan undang-undang?

Pendapat European Commission for Democracy through Law (Venice Commission) pada tahun 2006 dapat menjadi rujukan untuk menjawab pertanyaan tersebut. Venice Commission telah memberikan Opini No. 359/2005 tentang Perlindungan Hak Asasi Manusia dalam Situasi Darurat (Opinion on the Protection of Human Rights in Emergency Situations). Menurut Venice Commission, pembatasan HAM hanya dapat dilakukan oleh undang-undang karena adanya situasi darurat atau keadaan bahaya dan akan lebih baik jika didasarkan pada konstitusi. Konstitusi juga sebaiknya mendefinisikan situasi darurat atau keadaan bahaya yang dapat menjadi dasar bagi pembatasan HAM. ${ }^{26}$ Pasal 12 UUD 1945 sebenarnya juga mengenal konsep 'keadaan bahaya' yang dapat dinyatakan oleh presiden. Namun yang menjadi permasalahan, perpu dapat diundangkan oleh presiden tanpa perlu menyatakan 'keadaan bahaya'.

Oleh karena itu, konsep perpu yang membatasi derogable rights sebenarnya menjadi kontradiksi dengan jaminan dalam konstitusi. Pasal 28J UUD 1945 secara tegas menyatakan bahwa pembatasan harus ditetapkan dengan undang-undang dan tidak menyebutkan perpu sebagai instrumen yang dapat membatasi derogable rights. Inilah yang tampaknya menjadi kelemahan dalam penggunaan perpu sebagai alat membatasi derogable rights karena Perpu dibentuk tidak melalui prosedur di parlemen. Kondisi ini akan berbeda jika Indonesia mengenal mekanisme fast-track legislation seperti di Inggris yang membuka kemungkinan

26 European Commission for Democracy through Law (Venice Commission), Opinion on The Protection of Human Rights in Emergency Situations, Strasbourg: Council of Europe, 2016, hlm. 13. 
undang-undang disahkan dengan prosedur yang cepat oleh eksekutif dan parlemen dalam situasi genting.

Permasalahan lain yang muncul adalah jika pembatasan kebebasan berserikat dapat dilakukan dengan perpu, apakah pembatasan dalam perpu hanya dapat mengatur prosedur pembatasan melalui putusan pengadilan atau pembatasan tersebut dapat dilakukan pemerintah dengan keputusan tata usaha negara?

Prosedur yang disediakan dalam Perpu Ormas memang memberi kesempatan kepada pemerintah untuk membuat keputusan pencabutan status badan hukum ormas tanpa pertimbangan putusan pengadilan. Keputusan pencabutan status badan hukum ormas, sebagai suatu Keputusan Tata Usaha Negara (KTUN), dapat menjadi keputusan yang sewenang-wenang jika perpu juga menutup mekanisme kontrol terhadap keputusan tersebut. ${ }^{27}$ Namun demikian, Perpu Ormas sebenarnya tidak menutup mekanisme kontrol melalui lembaga peradilan karena tidak ada batasan untuk menggugat KTUN tersebut melalui Pengadilan Tata Usaha Negara (PTUN). Selain mekanisme kontrol dengan melakukan gugatan ke PTUN terhadap Keputusan Menteri Hukum dan HAM tentang pencabutan status badan hukum ormas, upaya hukum lain yang dapat ditempuh adalah mengajukan uji materiil perpu ke MK. Dengan demikian, upaya hukum dari ormas terkait masih tetap dapat dilakukan dalam berbagai mekanisme.

Adanya berbagai mekanisme untuk 'melawan' KTUN pembubaran ormas tersebut menunjukkan bahwa sistem hukum yang ada masih memberikan akses terhadap forum yang layak. Makna inti dari forum yang layak, menurut Bedner dan Vel, adalah apakah forum yang dimaksud mampu menawarkan jenis penyelesaian yang dibutuhkan oleh pencari keadilan. ${ }^{28}$ Sistem hukum di Indonesia memberikan peluang agar KTUN pencabutan status badan hukum dibatalkan melalui PTUN atau bahkan perpu yang digunakan sebagai landasan yuridis pencabutan status badan hukum dibatalkan oleh MK. Selain itu, akses terhadap kedua pilihan forum tersebut tidak memiliki hambatan yang signifikan secara sistemik. Hambatan dalam konteks ini merupakan hambatan yang meliputi: hambatan fisik, finansial, psikologis, dan aspek budaya.

Apakah prosedur pembubaran melalui pencabutan status badan hukum dan kemudian diberi kesempatan menggugat ke PTUN kurang demokratis jika dibandingkan pencabutan status badan hukum melalui putusan pengadilan? Menurut Penulis, perubahan mekanisme tersebut harus ditempatkan sebagai

27 Mekanisme kontrol melalui lembaga peradilan yang independen merupakan salah satu elemen negara hukum. Lihat Adriaan W. Bedner, "Suatu Pendekatan Elementer terhadap Negara Hukum", dalam buku Kajian SosioLegal, yang disusun oleh Adriaan W. Bedner, (et.al) (eds), Jakarta: Universitas Indonesia, Universitas Leiden, Universitas Groningen, 2012, hlm. 174-177.

28 Adriaan W. Bedner dan Jacqueline Vel, "Sebuah Kerangka Analisis untuk Penelitian Empiris dalam Bidang Akses terhadap Keadilan”, dalam Ibid., hIm. 101. 
kebijakan terbuka (open legal policy) dari pembentuk perpu karena UUD 1945 tidak mengatur secara kaku bahwa pembatasan kebebasan berserikat harus melalui putusan pengadilan. Dalam konteks peraturan perundang-undangan berbentuk undang-undang, kebijakan pembentukan undang-undang dikatakan bersifat terbuka (open legal policy) ketika UUD 1945 sebagai norma hukum yang lebih tinggi tidak mengatur atau tidak memberikan batasan jelas mengenai apa dan bagaimana materi tertentu harus diatur oleh undang-undang. Sebaliknya, kebijakan pembentukan undang-undang dikatakan bersifat tertutup jika UUD 1945 telah memberikan batasan jelas mengenai materi yang harus diatur dalam undangundang. ${ }^{29}$ Kebijakan terbuka tersebut dengan demikian harus dilihat dalam konteks perpu yang dibentuk dengan alasan kegentingan memaksa.

\section{Penutup}

Jika dilihat secara instrumental, Perpu Ormas dapat mengisi kekosongan hukum dalam kondisi kegentingan yang memaksa menurut tafsiran Presiden. Kegentingan yang memaksa dan kekosongan hukum membutuhkan penanganan cepat melalui pembentukan 'undang-undang' di luar prosedur biasa sehingga kemudian ditangani dengan perpu yang dapat dibentuk tanpa persetujuan DPR. Kondisi kekosongan hukum dalam kegentingan memaksa tersebut disebabkan UU Ormas sebelumnya tidak jelas mengatur ruang lingkup larangan melakukan tindakan permusuhan dan juga larangan ormas menganut paham yang bertentangan dengan Pancasila serta ingin mengganti Pancasila/UUD NRI 1945.

Namun demikian, Perpu Ormas masih memiliki kelemahan secara substansial. Pertama, pembatasan kebebasan menggunakan perpu memunculkan kelemahan dari sisi legitimasi karena minimnya diskursus yang deliberatif di ruang publik. Kedua, kedudukan Perpu Ormas dalam rangka mempertegas asas contrarius actus tidak tepat karena asas hukum (dalam konteks ini adalah contrarius actus) sebenarnya telah melekat pada pejabat pemerintah tanpa perlu ditegaskan dalam peraturan perundang-undangan. Ketiga, Perpu Ormas yang membatasi kemerdekaan berserikat sebagai derogable rights menjadi kontradiktif dengan jaminan dalam konstitusi. Pasal 28J UUD 1945 secara tegas menyatakan bahwa pembatasan harus ditetapkan dengan undang-undang dan tidak menyebutkan perpu sebagai instrumen yang dapat membatasi derogable rights.

29 Mardian Wibowo, "Menakar Konstitusionalitas Sebuah Kebijakan Hukum Terbuka dalam Pengujian UndangUndang", Jurnal Konstitusi, Vol. 12, No. 2, Juni 2015, hlm. 212. 


\section{Daftar Pustaka}

\section{Buku}

Ananda B. Kusuma, (et.al) (ed.), Risalah Sidang Badan Penyelidik Usaha-Usaha Persiapan Kemerdekaan Indonesia, Sekretariat Negara Republik Indonesia, Jakarta, 1992.

Bedner, Adriaan W., (et.al) (eds), Kajian Sosio-Legal, Universitas Indonesia, Universitas Leiden, Universitas Groningen, Jakarta, 2012.

Binsar Gultom, Pelanggaran HAM dalam Hukum Keadaan Darurat di Indonesia:

Mengapa Pengadilan HAM Ad Hoc di Indonesia Kurang Efektif?, PT Gramedia Pustaka Utama, Jakarta, 2010.

Committee on the Constitution, Fast-track Legislation: Constitutional Implications and Safeguards (15th Report of Session 2008-09), House of Lords UK Parliament, London, 2009.

European Commission for Democracy through Law (Venice Commission), Opinion on The Protection of Human Rights in Emergency Situations, Council of Europe, Strasbourg, 2016.

Herman Sihombing, Hukum Tata Negara Darurat di Indonesia, Djambatan, Jakarta, 1996.

Jimly Asshiddiqie, Hukum Tata Negara Darurat, PT. RajaGrafindo Persada, Jakarta, 2007.

Komisi Nasional Hak Asasi Manusia, Komentar Umum Kovenan Internasional Hak Sipil dan Politik, Kovenan Internasional Hak Ekonomi, Sosial, dan Budaya, Komisi Nasional Hak Asasi Manusia, Jakarta, 2009.

Victor Imanuel W. Nalle, Menggagas Hukum Berbasis Rasionalitas Komunikatif, Malang: UB Press, 2010.

Wintgens, Luc J. (ed), Legislation in Context: Essays in Legisprudence, Hampshire: Ashgate Publishing Limited, 2007.

\section{Dokumen Lain}

Feldman, William, "Theories of Emergency Powers: A Comparative Analysis of American Martial Law and the French State of Siege," Cornell International Law Journal, Vol. 38, Issue 3, 2005.

Ferejohn, John dan Pasquale Paquino, "The Law of the Exception: A Typology of Emergency Powers" International Journal of Constitutional Law, Vol. 2, No. 2, 2004.

Jakab, András, "German Constitutional Law and Doctrine on State of EmergencyParadigms and Dilemmas of a Traditional (Continental) Discourse", German Law Journal, Vol. 7, No. 5, 2006.

Mardian Wibowo, "Menakar Konstitusionalitas Sebuah Kebijakan Hukum Terbuka dalam Pengujian Undang-Undang", Jurnal Konstitusi, Vol. 12, No. 2, Juni 2015. 
Muhammad Syarif Nuh, "Hakekat Keadaan Darurat Negara (State Of Emergency) sebagai Dasar Pembentukan Peraturan Pemerintah Pengganti UndangUndang", Jurnal Hukum IUS QUIA IUSTUM, Vol. 18, No. 2, 2011.

Reza Fikri Febriansyah, "Eksistensi dan Prospek Pengaturan Perpu Dalam Sistem Norma Hukum Negara Republik Indonesia" Jurnal Legislasi Indonesia, Vol. 8, No. 4, 2012.

Victor Imanuel W. Nalle, "Blasphemy Law and Public Neutrality in Indonesia", Mediterannean Journal of Social Sciences, Vol. 8, No. 2, 2017.

\section{Dokumen Hukum}

Undang-Undang Dasar Negara Republik Indonesia Tahun 1945 Setelah Perubahan. Undang-Undang Nomor 12 Tahun 2011 tentang Pembentukan Peraturan Perundang-undangan.

Undang-Undang Nomor 17 Tahun 2013 tentang Organisasi Kemasyarakatan.

Peraturan Pemerintah Pengganti Undang-Undang Nomor 2 Tahun 2017 tentang Perubahan atas Undang-Undang Nomor 17 Tahun 2013 tentang Organisasi Kemasyarakatan.

Putusan Mahkamah Konstitusi Nomor 138/PUU-VII/2009 tentang Permohonan Pengujian Peraturan Pemerintah Pengganti Undang-Undang Nomor 4 Tahun 2009 tentang Perubahan atas Undang-Undang Nomor 30 Tahun 2002 tentang Komisi Pemberantasan Tindak Pidana terhadap Undang-Undang Dasar 1945, putusan diucapkan dalam Sidang Pleno Mahkamah Konstitusi yang terbuka untuk umum pada hariSenin, 8 Februari 2010.

Putusan Mahkamah Konstitusi Nomor 82/PUU-XI/2013, putusan diucapkan dalam Sidang Pleno Mahkamah Konstitusi yang terbuka untuk umum pada hari Selasa, 23 Desember 2014. 